\title{
Alzheimer's dementia and Multiple Sclerosis; using genetic engineering in their new therapeutics
}

\author{
Saif Aldeen AlRyalat* \\ School of Medicine, University of Jordan. 11942 Amman, Jordan
}

\begin{abstract}
Antibodies are rapidly evolving therapeutic approach, with different technologies developed for their production. In 2015,6 new antibodies were approved approved and 8 more are expected to be approved in 2016. A remarkable observation is that none of these antibodies related to neurological diseases, despite that the proposed treatments for the most common autoimmune and degenerative neurological diseases, i.e. Multiple Sclerosis and Alzheimer's dementia, respectively, are antibodies. The use of new genetic engineeritng technologies to establish bacterial expression systems that can provide new antibodies and more feasible alternative to produce existing antibodies.
\end{abstract}

\section{Introduction}

Neurological diseases, in general, are either having no treatment yet, e.g. Alzheimer's dementia, or are very difficult and expensive to treat, e.g. multiple sclerosis (MS). In 1993, 5 disease-modifying agents were approved for relapsing-remitting MS, the most common MS type, in which all were found to be marginally effective and expensive [1], with no treatment, yet, approved for Alzheimer's disease.

On the other hand, since its discovery in 1975 by Georges Kohler and Cesar Milstein [2], the use of genetic engineering in antibodies production is rapidly evolving with new expression systems being discovered and modified each day. Genetically-engineered expression systems can be used to produce drugs by cheap prokaryotic organisms, i.e., bacteria, instead of using the more expensive mammalian cells, i.e. the Chinese hamster ovary. Despite that, looking at the expression systems that are recently used to manufacture current treatments, we find that most of them are still using the old technologies that were developed in the 1970s and were adapted for biopharmaceutical manufacture in the 1980s [3]. In this commentary, I am going to discuss the benefits of using modern genetic engineering methods to provide cheaper and more effective therapeutic agents, particularly for neurological diseases.

\section{Discussion}

One of the best examples on how incorporating genetic engineering in drug development can significantly reduce the cost of useful therapeutic agents is the anti-angiogenic antibodies that are used in the treatment of age-related macular degeneration. Anti-angiogenic antibodies used to cost around $\$ 2000$ per dose when it was produced via the Chinese hamster ovary (Bevacizumab), but when genetic engineering technologies were invested for the production of antiangiogenic antibodies via bacteria (Ranibizumab), the cost per dose was massively reduced to around $\$ 50[4]$.

A similar approach can be applied in most neurological diseases, as antibodies are currently the mainstay for treatment of neurological autoimmune diseases; e.g. MS, and are the proposed future treatment for Alzheimer's dementia as well [5]. The annual cost of monoclonal antibodies that were used for MS treatment in 1993 was estimated to be around $\$ 11,500$, compared to around $\$ 60,000$ in 2013 , the majority of this massive increase in treatment cost is due to the very high production costs [6]. This show how new cheaper methods to produce these antibodies are mandatory.

3 main hosts; bacteria, yeast, and mammalian cells, are used to produce $87 \%$ of all recombinant proteins [7]. Of these, bacteria are the most widely used, the easiest, and the least expensive host. In 1982, insulin was produced by E. coli for the first time and was approved by FDA. Two years later, Cabilly, et al., reported the first full-length antibody produced by $E$. coli, but these antibodies lack the glycan group usually present in monoclonal antibodies, so that they were termed "Aglycosylated antibodies" [8]. Since then, modifications to all steps of aglycosylated antibodies production were published, leading, for some instances, to 160 times better binding affinity compared to their glycosylated counterparts [9], with production yield reaching up to 1 gram/Liter in fed batch fermentation [10].

Antibodies are rapidly evolving therapeutic approach with $104 \%$ increase in involvement of antibodies in phase 3 clinical trials from 2009 to 2014 [11]. Owing to their outstanding high selectivity, low toxicity, and prolonged serum half-life (3-4 weeks), monoclonal antibodies represent the best therapeutic approach for neurological diseases, particularly, MS and Alzheimer's dementia. Despite that, in 2015 and 2016, no new antibody was approved or reviewed for approval as therapeutic agents for any neurological disease.

Correspondence to: Saif Aldeen Saleh AlRyalat, School of Medicine, University of Jordan. 11942 Amman, Jordan, Tel: +962-798914594, E-mail: Saifryalat@yahoo.com

Key words: Multiple sclerosis, Alzheimer's dementia, genetic engineering, antibodies, bacterial expression system

Received: November 04, 2016; Accepted: December 02, 2016; Published: December 06, 2016 


\section{Conclusion}

Aglycosylated antibodies are antibodies that are produced by prokaryotic expression systems with relatively low cost. Providing that the treatment approach for the most common autoimmune neurological disease; MS, and the most common degenerative neurological disease; Alzheimer's dementia, are proposed to be antibodies, more research should be done on how we can use these expression systems to beat these neurological diseases with the lowest possible cost.

\section{References}

1. Vollmer T, Key L, Durkalski V, Tyor W, Corboy J, et al. (2004) Oral simvastatin treatment in relapsing-remitting multiple sclerosis. Lancet 363: 1607-1608. [Crossref]

2. Köhler G, Milstein C (1975) Continuous cultures of fused cells secreting antibody of predefined specificity. Nature 256: 495-497. [Crossref]

3. Rader RA (2008) (Re)defining biopharmaceutical. Nat Biotechnol 26: 743-751. [Crossref]

4. Stein JD, Newman-Casey PA, Mrinalini T, Lee PP, Hutton DW (2014) Costeffectiveness of bevacizumab and ranibizumab for newly diagnosed neovascular macular degeneration. Ophthalmology 121: 936-945. [Crossref]
5. Reichert JM (2013) Antibodies to watch in 2013: Mid-year update. In MAbs Taylor \& Francis 5: 513-517. [Crossref]

6. Hartung DM, Bourdette DN, Ahmed SM, Whitham RH (2015) The cost of multiple sclerosis drugs in the US and the pharmaceutical industry: Too big to fail? Neurology 84 : 2185-2192. [Crossref]

7. Demain AL, Vaishnav P (2009) Production of recombinant proteins by microbes and higher organisms. Biotechnology advances 27: 297-306. [Crossref]

8. Ju MS, Jung ST (2014) Aglycosylated full-length IgG antibodies: steps toward nextgeneration immunotherapeutics. Current opinion in biotechnology 30: 128-139. [Crossref]

9. Borrok MJ, Jung ST, Kang TH, Monzingo AF, Georgiou G (2012) Revisiting the role of glycosylation in the structure of human IgG Fc. ACS Chem Biol 7: 1596-1602. [Crossref]

10. Reilly DE, Yansura DG (2010) Production of monoclonal antibodies in E. coli. In Current Trends in Monoclonal Antibody Development and Manufacturing Springer New York 295-308. [Crossref]

11. Reichert JM (2016) Antibodies to watch in 2016. In MAbs Taylor \& Francis 8: 197 204. [Crossref]

Copyright: $@ 2016$ AlRyalat SA. This is an open-access article distributed under the terms of the Creative Commons Attribution License, which permits unrestricted use, distribution, and reproduction in any medium, provided the original author and source are credited. 